\title{
ラクトフェリンによる化学療法剤処理魚の副作用軽減
}

\author{
高瀬清美, 角田 出*

\section{Lactoferrin Reduces Physiological Dysfunctions of Goldfish Induced by Chemotherapeutic Agents}

\author{
Kiyomi TAKASE and Izuru KAKUTA* \\ Department of Biological Engineering, Senshu University of Ishinomaki, 1 Shinmito Minamisakai, \\ Ishinomaki City 986-8580, Japan
}

(Received January 12, 2007; Accepted June 8, 2007)

\begin{abstract}
We investigated whether the deleterious side effects of chemotherapeutic agents on the physiologic functions of fish could be modulated by lactoferrin (LF). Goldfish, weighing about $25 \mathrm{~g}$, were treated intramuscularly with methotrexate (MTX: $2.5 \mathrm{mg} / \mathrm{kg}$ body weight) and fluorouracil (FU: 15 or $50 \mathrm{mg} / \mathrm{kg}$ body weight) three times every other day. In control fish fed a commercial diet, MTX induced severe immunosuppression, increased the number of total bacteria and Enterobacteriaceae in the intestinal tract, and caused intestinal damage such as lowered and thickened mucosa and thinned muscularis externa, with moderate renal dysfunction. A few fish treated with MTX died. In fish injected with FU or FU plus MTX, the side effects were slightly less in comparison with those in the MTX group. Pretreatment with LF (oral administration at $200 \mathrm{mg} / \mathrm{kg}$ body weight/day) for 3 weeks reduced the deleterious side effects of MTX and FU. One intraperitoneal injection of LF ( $200 \mathrm{mg} / \mathrm{kg}$ body weight) immediately after the first MTX injection also reduced the side effects. These results show that LF reduces the physiologic dysfunction of fish treated with chemotherapeutic agents.
\end{abstract}

Key words — methotrexate; side effects; lactoferrin; immunity; intestinal damage; chemotherapeutic agents

\section{緒言}

哺乳類において, 腫瘍の治療は, 化学療法剂の投 与, 切除手術, 放射線照射等により行われている. 近年，化学療法剤による治療は新薬を見出すことに 加え，複数の化学療法剂を用いて治療効果を高める 多剂併用療法の検討が行われ，その治療成績は日々 向上している。しかし，強力な化学療法剤の投与 は，強い副作用をも引き起こす. ${ }^{1)}$ 高い効果を得る ための投与量増加も, 同様の結果を生む. 化学療法 剂は主に未分化の腫瘍細胞に作用するため, 細胞分 裂が活発である免疫担当細胞や消化管内膜等はその 影響を受け易い。その他の臓器でも細胞分裂の充進 に伴い，様々な副作用が発現する，例えば，代謝拮 抗作用を持つ化学療法剂であるメトトレキサート (MTX) は，プリンヌクレオチドの de novo 生合成 阻害, dUMP から dTMP への変換阻害を行うこと により抗腫瘍性を示す。 ${ }^{2}$ 副作用として, 液性免疫

石巻専修大学理工学部生物生産工学科

*e-mail: kakuta@isenshu-u. ac.jp
応答の阻害, ${ }^{3)}$ 小腸の上皮細胞損傷 ${ }^{4}$ が報告されて いる。 また，MTX 投与時には，フルオロウラシル （FU）など，他の薬剤と併用することも多い．FU も重症腸炎を引き起こすことが報告されている.5) 化学療法剂の効果を十分に得るためには, 同時に その副作用を軽減していく必要がある，化学療法剂 の副作用軽減法としては, 補助食品による免疫力の 増強，他の薬剂投与による救援療法等の処置が採ら れてきた。しかしながら，従来の方法では十分な副 作用軽減処置効果を得られていないのが実情である.

ラクトフェリン（LF）は，初乳中に特に高濃度 に含まれる，鉄結合性蛋白質である，LF は体内の 非特異的生体防御機構を賦活化することにより，抗 菌, 6) 抗ウイルス, ${ }^{7)}$ 抗真菌, ${ }^{8)}$ 抗寄生虫, ${ }^{9,10)}$ 抗腫瘍 作用11-14)などを示す。加えて，LF が抗腫瘍剤の副 作用を軽減する効果についても，マウスにおいて， シクロヘキシミドによって生じるリンパ球数の減少 を抑制したり, ${ }^{15)} \mathrm{MTX}$ の投与によって生じる小腸 上皮細胞の障害を軽減したりすること年が報告され ている. 
腫瘍形成は魚においても認められており，ニシキ ゴイには腹部が著しく膨大する “腸満” と呼ばれる 疾病がある，腸満は，腹部の膨張，立鱗，背こけ等 の症状を伴う，コイの卵巣腫瘍である. ${ }^{17)}$ 罹病魚は 遊泳が緩慢になり，衰弱し，死に至ることがある。 魚類における腫瘍形成は，卵巣以外に皮膚や肝臓で も認められる. ${ }^{18,19)}$ 魚の腫瘍は，早期発見ができれ ば，手術による治癒の望みがある。日頃から魚に触 れることの多い業者等であれば，腫瘍の早期発見は 可能である。しかし，手術には専門的な知識と技術 が要求され，一般愛好者や業者ではほとんど不可能 である。 また，長時間に渡る空気中への暴露は個体 に大きなストレスを与えるとともに，その術跡は二 シキゴイを始めとする高級観賞魚にとって致命的で ある.よって，手術に代わる腫瘍の治療法として， 化学療法剂の使用も検討されるべきである，その場 合, 化学療法剂による副作用の軽減法についての研 究は必須である。

現在，実験動物としての魚類は，「動物の愛護及 び管理に関する法律」による規制を受けていない．

しかし，メダカ，ゼブラフィッシュでは，多くの突 然変異体が見付かっており，ヒトの疾患モデルとし て注目を集めている。また，これらの魚は小型で飼 育が容易であり，世代交代が早い。よって，魚類は 実験動物として利用価値が高く，哺乳類に代わる実 験動物としても有望である.

そこで本研究では，キンギョに化学療法剤を投与 し，その影響（副作用）を調査するとともに，LF の事前及び同時投与による副作用の軽減効果を調べ た.

\section{材料及び方法}

1. 供試魚供試魚として体重 $25 \mathrm{~g}$ 前後のキ ンギョCarassius auratus を用いた。キンギョは, 水温 $20^{\circ} \mathrm{C}$ に調整した, 容量 20001 の循環濾過式水 槽内で 2 週間以上予備飼育したのち，実験に供し た。予備飼育期間中は市販の餌を，一日当たり魚体 重の $2 \%$ 量投与した。

\section{2. 飼育試験}

2-1. 化学療法剤投与試験 A（LF の事前経口投 与試験） キンギョを 20 尾ずつ 8 群に分け，各 群，水温 $20^{\circ} \mathrm{C}$ に調節した容量 601 の循環濾過式水 槽に収容した。 4 群に前述の市販飼料（対照区：C
区)，残りの 4 群には同飼料に牛ラクトフェリン （LF：森永乳業(侏製）を添加した餌（LF 投与区） を，それぞれ毎日体重の $2 \%$ 量投与し 7 週間飼育し た。 LF の一日当たりの投与量は $200 \mathrm{mg} / \mathrm{kg}$ 体重で ある。

上記飼育開始から 3 週間を経過した時点で，対照 区と LF 投与区のキンギョを， $0.75 \%$ 生理食塩水を 投与したもの（C-S 群と LF-S 群）と化学療法剂の メトトレキサート（MTX）を投与したもの（C-M 群と LF-M 群)，フフルオウラシル（FU）を投与し たもの（C-F 群と LF-F 群），MTX 及び FU を混合 投与したもの（C-MF 群と LF-MF 群）の計 8 群に 分け， 4 週間の飼育試験を行った。なお，化学療法 剂は $0.75 \%$ 生理食塩水中に懸濁し，一日おきに 3 回，筋肉内投与した。一日当たりの化学療法剂投与 量は，単独投与群の場合は，MTX $2.5 \mathrm{mg} / \mathrm{kg}$ 体重 あるいは FU $50 \mathrm{mg} / \mathrm{kg}$ 体重，混合投与群では MTX $2.5 \mathrm{mg} / \mathrm{kg}$ 体重及び FU $15 \mathrm{mg} / \mathrm{kg}$ 体重とし た。なお，MTX と FU の混合投与群では，MTX を投与した一時間後に FU の投与を行った.

2-2. 化学療法剤投与試験 B (LF の同時腹腔内 投与試験） キンギョを 15 尾ずつ 2 群に分け，と もに，水温 $20^{\circ} \mathrm{C}$ に調節した容量 601 の循環濾過式 水槽に収容した。両群に前述の市販飼料を毎日体重 の $2 \%$ 量投与し， 4 週間飼育した.

上記飼育開始から 2 週間を経過した時点で， 0.75 \%生理食塩水あるいは MTX を，一日おきに 3 回， 筋肉内投与した。化学療法剂の投与初日にのみ，キ ンギョの腹腔内に $0.75 \%$ 生理食塩水（対照群）あ るいは LF を溶解した同食塩水 (LF 群) を投与し, 2 週間の飼育試験を行った。なお，MTXの投与量 は一日当たり $2.5 \mathrm{mg} / \mathrm{kg}$ 体重, LF 群への LF の投 与量は $200 \mathrm{mg} / \mathrm{kg}$ 体重とした。

\section{3. 生理指標の調査}

3-1. 血球数の計測 実験 $\mathrm{A}$ ，実験 $\mathrm{B}$ ともに MTX 投与後 1 週間目及び 2 週間目に各群より 5 尾 を取り上げ，ヘパリンリチウム処理した注射器を用 い，尾部血管より採血を行った。採血した血液を試 料として，血球計算法により，赤血球数を測定し た.また，血球塗抹標本にメイグリュンワルド・ギ ムザ染色を施し，赤血球 5000 個当たりの顆粒球数 とリンパ球数を計測した.

\section{3-2. 顆粒球の貪食率の測定ザイモザンに対}


する顆粒球の䕘食能を以下のようにして測定した。 $0.75 \%$ 生理食塩水中にザイモザン（シグマ社製）を $0.5 \mathrm{mg} / \mathrm{ml}$ となるよう懸濁させたのち，超音波処理 によって均一化した同液と全血を等量ずつ混合し， $20^{\circ} \mathrm{C}$ で 20 分間，振とう条件下で反応させた。 反応 終了後，均一化した反応液の一部をスライドグラス に滴下し，直ちに塗抹，風乾したのち，メイグリュ ンワルド・ギムザ染色を施して検鏡した。領食能は

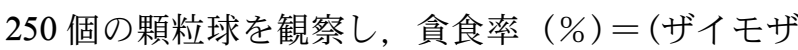
ンを食した顆粒球数/観察した顆粒球数) $\times 100$ とし て求めた.

\section{3-3. 顆粒球のニトロテトラゾリウム（NBT）還} 元活性食食反応終了後, 同反応液の一部を, 2 $\mathrm{mg} / \mathrm{ml}$ となるようにニトロブルーテトラゾリウム （和光純薬社製）を溶解した $0.75 \% \mathrm{NaCl}$ を含む 1 / 30 モルのリン酸緩衝液（pH 7.2）と 1 : 2 の割合で 混合し， $20^{\circ} \mathrm{C}$ で 30 分間反応させた．その後，反応 液をスライドクラスに塗抹，風乾後，メイグリュン ワルド・ギムザ染色を施して検鏡した。NBT 還元 活性は 100 個の顆粒球を観察し，ホルマザンを形成 している顆粒球の出現率(陽性率) として表記した.

3-4. 血漿中一価イオンの測定血漿中の $\mathrm{Na}$, $\mathrm{K}, \mathrm{Cl}$ は電極法（富士ドライケム DRI-CHEM 800） により測定した。

\section{3-5. 組織学的観察 化学療法剂投与試験 $\mathrm{A}$,} 化学療法剂投与試験 B ともに，採血を終えた個体 より腸管，肝臓，体腎を採取した。腸管について は，肛門から $20 \mathrm{~mm}$ 程度離れた部位（腸後部）と， 肛門から $130 \mathrm{~mm}$ 程度離れた部位（腸中部）をそれ ぞれ約 $10 \mathrm{~mm}$ の幅で採取した。各組織片はブアン 液で固定し, 常法に従って $6 \mu \mathrm{m}$ のパラフィン切片 を作製し，HE 染色後，検鏡した。なお，腸壁筋層 の厚みは連続する 5 枚の切片について観察し， 1 枚 の切片について無作為に 3 力所を選び筋層（輪状筋 十縦走筋）の厚みを計測し，その平均值を調査個体 の值とした。

3-6. 腸内細菌数の測定化学療法剂投与直 前, 化学療法剂投与後 2 週間目及び 4 週間目に, 各 群より取り上げた 4 尾の腸内容物を試料とした。肛 門から $30 \mathrm{~mm}$ 程度離れた部分より前方約 $100 \mathrm{~mm}$ の長さで腸管を無菌的に切り出した．腸内容物を搾 り出したのち， $0.75 \%$ 生理食塩水を加えてホモジナ イズし，試料溶液を調製した。
腸内全細菌数の調査には，最終濃度で $10 \mathrm{mg} / 1$ と なるようにへミン（和光純薬社製）を加えたトリプ トソーヤ寒天培地（日水製薬社製）と BL 寒天培地 （栄研器材社製）を用いた。トリプトソーヤ寒天培 地は好気条件下，BL 寒天培地は嫌気条件下で，そ れぞれ室温で 5 日間培養したのち，コロニー数を計 測した。計数後，BL 寒天培地に生育したコロニー については形状観察を行うとともに，各群から無作 為に 33 個のコロニーを新たな $\mathrm{BL}$ 寒天培地に釣菌 して好気条件下で培養し，好気条件下での生育の有 無を調べ，偏性嫌気性菌であるBacteroidaceae を同 定した。なお，好気性細菌数に偏性嫌気性細菌であ る Bacteroidaceae の数を加えたものを腸内全細菌数 とした.

大腸菌群については，上記，計数後のトリプト ソーヤ寒天培地より，無作為に 33 個のコロニーを ES コリマーク寒天培地（栄研器材社製）に釣菌し, 常法に従い $37^{\circ} \mathrm{C}$ で 1 日間培養後，赤色のコロニー 数を計測し, 大腸菌群数とした。

3-7. 統計 化学療法剂投与試験 $\mathrm{A}$ で得られた 結果については，取り上げ時期毎に対照区及び LF 投与区間では Tukeyの多重比較検定を，対照区と LF 投与区の比較及び化学療法剂投与試験 B の結果 については Welchの検定を，それぞれ行い， $p<$ 0.05 を有意の限界とした。 また，本文中では，特 記しない場合, 平均值士標準偏差（腸内細菌数につ いては $n=4$, それ以外は $n=5 ）$ で表した.

\section{結果}

\section{1. 化学療法剂投与試験 A（LF の事前経口投与} 試験） 化学療法剂の投与前では，対照区及び LF 投与区とも，飼育期間中の餌の食いは良好であ り，外見や行動に異常は認められなかった。両区の 体重，体長にも有意な差は認められなかった．化学 療法剂を投与した対照区の魚は，体表に損傷のみら れる場合が多く，特に，MTX 投与群では，取り上 げ時に鱗が剥がれ易く，腸管も切れ易く脆かった. 一方，LF 投与区の魚には，上記の変化は認められ なかった。

1-1. 生残率 LF の事前の経口投与が化学療 法剂投与魚の生残率に及ぼす影響を Fig. 1 に示 す。化学療法剂投与試験開始から 4 週間目まで, C-S 群及び LF 投与区（4 群とも）に死亡個体は認 


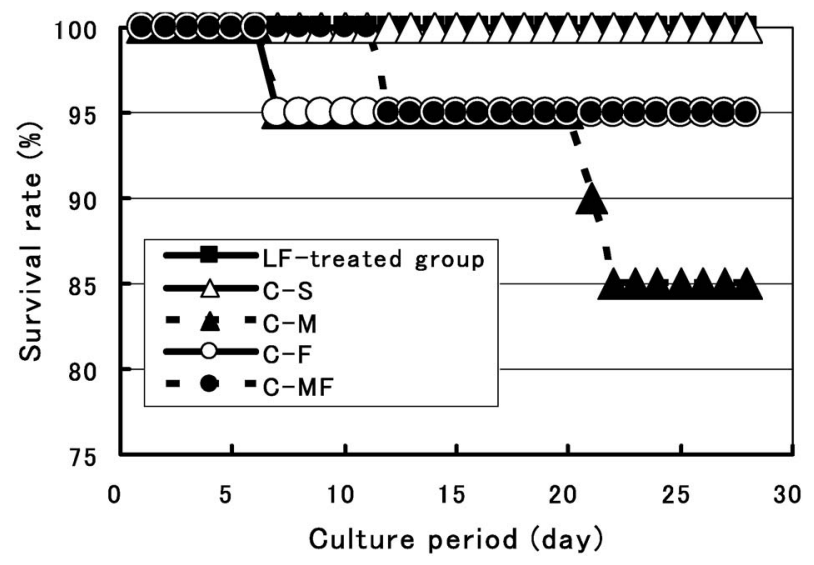

Fig. 1. Changes in the Survival Rate of Goldfish Treated with Chemotherapeutic Agents

In LF-treated group, goldfish were fed LF for 3 weeks before the agent treatment. LF-treated group: LF-S, LF-M, LF-F and LF-MF groups.

められなかった。それに対し，化学療法剤を投与し た対照区の各群では，死亡個体が認められ，4 週間 目における C-F 群及び C-MF 群の生残率は，とも に $95 \%$ となった。特に，C-M 群では，化学療法剤 投与後 1 週間目当たりから死亡個体が出始め, 4 週 間目では 85\%にまで低下した。

1-2. 血球組成化学療法剤投与直前の対照区 及び LF 投与区の赤血球数 $\left(10^{6}\right.$ 個 $\left./ \mathrm{mm}^{3}\right)$, 顆粒球 数 $\left(10^{4}\right.$ 個 $\left./ \mathrm{mm}^{3}\right)$, リンパ球数 $\left(10^{4}\right.$ 個 $\left./ \mathrm{mm}^{3}\right)$ は, それぞれ，1.14 0.36 及び $1.75 \pm 0.13,1.52 \pm 0.46$ 及び $4.37 \pm 1.08,0.38 \pm 0.09$ 及び $0.30 \pm 0.14$ であっ た. LF 投与区の顆粒球数は，対照区に比へ，有意 に高い值を示した。ただし，赤血球数とリンパ球数 では，対照区と LF 投与区の間に有意な差はみられ なかった。

化学療法剂投与後 2 週間目, 4 週間目の対照区及 び LF 投与区の血球数を Table 1 に示す．赤血球数 及びリンパ球数については，2 週間目，4 週間目と もに，すべての試験群間に有意な差は認められなか つた。顆粒球数については，4 週間目にのみ，C$\mathrm{MF}$ 群が C-S 群に対し有意に低い值を示した。 上記 を除く対照区内の比較では，取り上げ時期を問わ ず，各群間に有意な差は認められなかつた。また， LF 投与区内においても，各群間に差は認められな かった。

対照区と LF 投与区の比較では，2 週間目におい ては LF-S 群，LF-M 群，LF-MF 群はそれぞれ， C-S 群，C-M 群，C-MF 群に対し，4 週間目におい

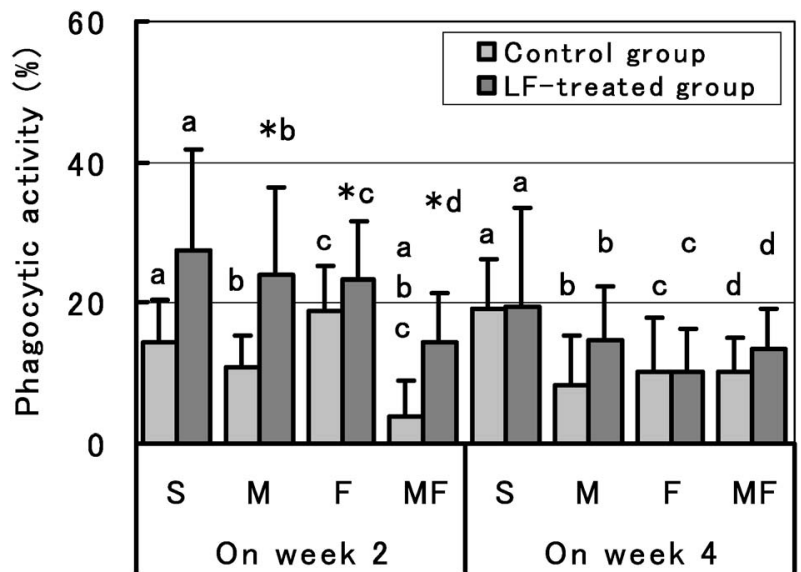

Experimental period

Fig. 2. Changes in the Phagocytic Activity of Granulocytes from Goldfish Treated with Chemotherapeutic Agents

In LF-treated group, goldfish were fed LF for 3 weeks before the agent treatment. S: saline, M: methotrexate $(2.5 \mathrm{mg} / \mathrm{kg} \mathrm{BW} /$ day $)$, F: fluorouracil $(50 \mathrm{mg} / \mathrm{kg} \mathrm{BW} /$ day $)$, MF: methotrexate $(2.5 \mathrm{mg} / \mathrm{kg} \mathrm{BW} /$ day $)$ and fluorouracil $(15 \mathrm{mg} / \mathrm{kg} \mathrm{BW} /$ day $)$. Data are given as mean \pm S.D., $n=5$. a-d: The same superscript in each group at the same period indicates a significant difference $(p<0.05)$. *Significant difference to the control $(p<0.05)$.

ては，LF-S 群， LF-M 群， LF-F 群，LF-MF 群は それぞれ，C-S 群，C-M 群，C-F 群，C-MF 群に対 し有意に高い值を示した。

1-3. 顆粒球の貪食率化学療法剂投与直前の 対照区及び LF 投与区における顆粒球の䕘食率 (\%) は，29.9土9.78 及び $53.0 \pm 21.2$ であり，両区間に 有意な差は認められなかった。

LF の経口投与が化学療法剤投与魚の顆粒球の貪 食率に及ぼす影響を Fig. 2 に示す。 2 週間目にのみ, C-MF 群は C-S 群， C-M 群， C-F 群に対し有意に 低い值を示した。 上記を除く対照区内の比較では, 取り上げ時期を問わず，各群間に有意な差は認めら れなかった。 また, LF 投与区内においても, 各群 間に差は認められなかった。

対照区と LF 投与区の比較では， 2 週間目にのみ, LF-M 群，LF-F 群，LF-MF 群は，それぞれ，C-M 群，C-F 群，C-MF 群に対し有意に高い值を示した.

1-4. NBT 還元活性化学療法剂投与直前の 対照区及び LF 投与区の NBT 還元活性率（\%）は $6.4 \pm 3.5$ 及び $27.8 \pm 12.5$ であった。 LF 投与区は対 照区に対し有意に高い值を示した。

LF の経口投与が化学療法剂投与魚の顆粒球の NBT 還元活性に及ぼす影響を Fig. 3 に示す。対照 区，LF 投与区ともに，同一区内の比較では，取り 
Table 1. Changes in the Number of Red Blood Cells, Granulocytes and Hymphocytes from Goldfish Treated with Chemotherapeutic Agents

\begin{tabular}{|c|c|c|c|c|}
\hline & $\begin{array}{l}\text { Body weight } \\
(\mathrm{g})\end{array}$ & $\begin{array}{c}\mathrm{RBC} \\
\left(\times 10^{6} \text { cells } / \mathrm{mm}^{3}\right)\end{array}$ & $\begin{array}{c}\text { Granulocyte } \\
\left(\times 10^{4} \text { cells } / \mathrm{mm}^{3}\right)\end{array}$ & $\begin{array}{c}\text { Lymphocyte } \\
\left(\times 10^{4} \text { cells } / \mathrm{mm}^{3}\right)\end{array}$ \\
\hline \multicolumn{5}{|l|}{ Experimental A } \\
\hline \multicolumn{5}{|l|}{ (Oral adiministration) } \\
\hline \multicolumn{5}{|l|}{ On week 2} \\
\hline \multicolumn{5}{|l|}{ Control group } \\
\hline C-S*1 & $25.0 \pm 6.2^{a)}$ & $1.96 \pm 0.62^{a)}$ & $0.95 \pm 0.56^{a)}$ & $0.14 \pm 0.08^{a)}$ \\
\hline $\mathrm{C}-\mathrm{M}^{* 2}$ & $27.0 \pm 6.1^{b)}$ & $2.39 \pm 0.42^{b)}$ & $1.47 \pm 0.32^{b)}$ & $0.19 \pm 0.10^{b)}$ \\
\hline $\mathrm{C}-\mathrm{F}^{* 3}$ & $31.5 \pm 6.3^{c)}$ & $2.47 \pm 0.16^{c)}$ & $0.89 \pm 0.66^{c)}$ & $0.28 \pm 0.13^{c)}$ \\
\hline $\mathrm{C}-\mathrm{MF}^{* 4}$ & $25.7 \pm 4.4^{d)}$ & $1.87 \pm 0.58^{d)}$ & $0.97 \pm 0.27^{d)}$ & $0.22 \pm 0.09^{d)}$ \\
\hline \multicolumn{5}{|l|}{ LF-treated group } \\
\hline LF-S & $23.6 \pm 4.4^{a)}$ & $\left.2.16 \pm 0.69^{a}\right)$ & $1.95 \pm 0.80^{a) *}$ & $\left.0.26 \pm 0.08^{a}\right)$ \\
\hline LF-M & $24.3 \pm 3.3^{b)}$ & $2.33 \pm 0.65^{b)}$ & $1.67 \pm 0.28^{b) *}$ & $0.23 \pm 0.05^{b)}$ \\
\hline LF-F & $25.9 \pm 5.5^{c)}$ & $2.39 \pm 0.99^{c)}$ & $1.79 \pm 0.97^{c)}$ & $0.22 \pm 0.08^{c)}$ \\
\hline LF-MF & $25.7 \pm 4.4^{d)}$ & $2.49 \pm 0.65^{d)}$ & $1.56 \pm 0.34^{d) *}$ & $0.18 \pm 0.04^{d)}$ \\
\hline \multicolumn{5}{|l|}{ On week 4} \\
\hline \multicolumn{5}{|l|}{ Control group } \\
\hline C-S & $32.6 \pm 11.4^{a)}$ & $2.33 \pm 0.40^{a)}$ & $0.99 \pm 0.18^{a)}$ & $0.28 \pm 0.03^{a)}$ \\
\hline C-M & $30.6 \pm 10.8^{b)}$ & $2.17 \pm 0.50^{b)}$ & $0.77 \pm 0.25^{b)}$ & $1.23 \pm 0.05^{b)}$ \\
\hline $\mathrm{C}-\mathrm{F}$ & $26.0 \pm 11.5^{c}$ & $1.42 \pm 0.72^{c)}$ & $0.81 \pm 0.31^{c)}$ & $0.30 \pm 0.12^{c)}$ \\
\hline C-MF & $28.3 \pm 11.3^{d)}$ & $1.88 \pm 0.53^{d)}$ & $0.55 \pm 0.30^{a)}$ & $0.34 \pm 0.15^{d)}$ \\
\hline \multicolumn{5}{|l|}{ LF-treated group } \\
\hline LF-S & $28.2 \pm 7.2^{a)}$ & $2.56 \pm 0.20^{a)}$ & $2.12 \pm 0.61^{a) *}$ & $0.34 \pm 0.09^{a}$ \\
\hline LF-M & $26.3 \pm 4.9^{b)}$ & $1.80 \pm 0.67^{b)}$ & $1.50 \pm 0.39^{b) *}$ & $0.29 \pm 0.08^{b)}$ \\
\hline LF-F & $31.9 \pm 7.8^{c)}$ & $1.55 \pm 0.57^{c)}$ & $1.99 \pm 0.50^{c)} *$ & $\left.0.34 \pm 0.14^{c}\right)$ \\
\hline LF-MF & $29.8 \pm 8.7^{d)}$ & $1.78 \pm 0.34^{d)}$ & $1.50 \pm 0.23^{d) *}$ & $0.21 \pm 0.08^{d)}$ \\
\hline \multicolumn{5}{|c|}{$\begin{array}{l}\text { Experimental B } \\
\quad \text { (Intraperitoneal injection) }\end{array}$} \\
\hline Control group & $21.1 \pm 3.2$ & $1.14 \pm 0.36$ & $1.52 \pm 0.46$ & $0.56 \pm 0.35$ \\
\hline LF-treated group & $24.1 \pm 4.5$ & $1.62 \pm 0.32$ & $4.56 \pm 1.57^{*}$ & $0.96 \pm 0.61$ \\
\hline
\end{tabular}

Chemotherapeutic agents were administered intramuscularly three times every other day. In the experimental A, goldfish were administered orally lactoferrin (LF) for 3 weeks before the agent treatment. In the experimental B, LF was injected intraperitoneally just after the agent treatment. ${ }^{{ }_{1}} \mathrm{~S}$ : saline, ${ }^{* 2} \mathrm{M}$ : methotrexate $(2.5 \mathrm{mg} / \mathrm{kg} \mathrm{BW} /$ day $),{ }^{*_{3}} \mathrm{~F}$ : fluorouracil $(50 \mathrm{mg} / \mathrm{kg} \mathrm{BW} /$ day $),{ }^{* 4} \mathrm{MF}$ : methotrexate $(2.5 \mathrm{mg} / \mathrm{kg}$ $\mathrm{BW} /$ day $)$ and fluorouracil $(15 \mathrm{mg} / \mathrm{kg} \mathrm{BW} /$ day). Data are given as mean \pm S.D., $n=5 . a-d)$ The same superscript in each group at the same period indicates a significant difference $(p<0.05) .{ }^{*}$ Significant difference to the control $(p<0.05)$.

上げ時期を問わず，各群間に有意な差は認められな かった.

対照区と LF 投与区の比較では，2 週間目におい て，LF-C 群，LF-M 群，LF-F 群はそれぞれ C-S 群, C-M 群，C-F 群に対し有意に低い值を示した. 4 週 間目については，LF-M 群，LF-F 群，LF-MF 群は それぞれ，C-M 群， C-F 群， C-MF 群に対し有意 に高い值を示した。

1-5. 血漿中の一価イオン濃度化学療法剂投 与直前の対照区及び LF 投与区の血漿中の $\mathrm{Na}, \mathrm{K}$, $\mathrm{Cl}$ の濃度 $(\mathrm{mEq} / \mathrm{l})$ はそれぞれ $107 \pm 21.1$ 及び 121 $\pm 24.1,5.24 \pm 2.52$ 及び $4.84 \pm 4.13,86.6 \pm 14.1$ 及び
95.4 \pm 14.3 であった. LF 投与区と対照区の間で, $\mathrm{Na}, \mathrm{K}, \mathrm{Cl}$ の值に有意な差は認められなかった。ま た，化学療法剂の投与後でも，調査した時期を問わ ず，すべての群間において有意な差は認められなか つた.

1-6. 組織学的観察 腸管の上皮細胞について は，C-M 群， C-MF 群では, 粘膜ひだの肥厚及び 顆粒球の粘膜上皮組織への浸潤が高い頻度で観察さ れ，特に C-M 群の変化は大きかった。 また，C-M 群の一部の個体では，粘膜ひだの高さの低下した像 や陰窩が粘膜筋板にまで達している像も観察され た。一方，LF 投与区では，上記の化学療法剤投与 


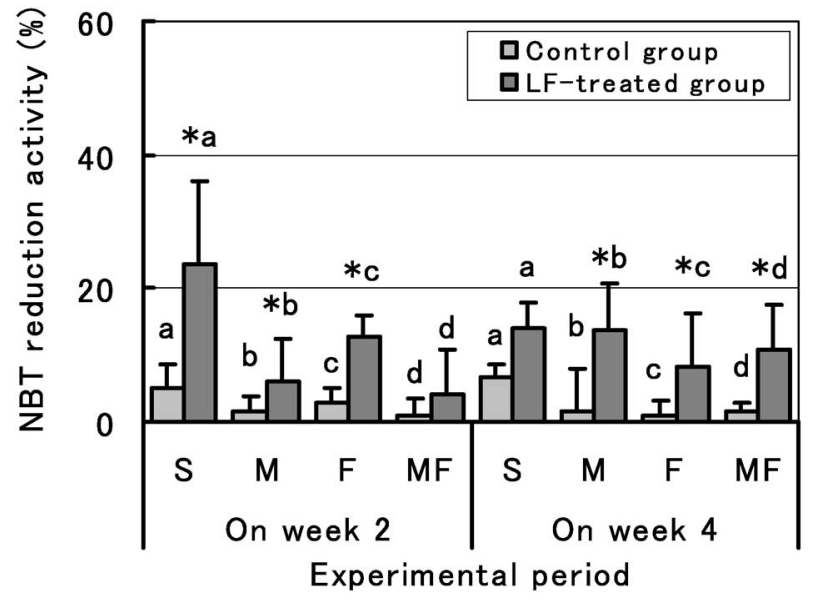

Fig. 3. Changes in the NBT Reduction Activity of Granulocytes from Goldfish Treated with Chemotherapeutic Agents In LF-treated group, goldfish were fed LF for 3 weeks before the agent treatment. S: saline, M: methotrexate $(2.5 \mathrm{mg} / \mathrm{kg} \mathrm{BW} /$ day $)$, F: fluorouracil $(50 \mathrm{mg} / \mathrm{kg} \mathrm{BW} /$ day $)$, MF: methotrexate $(2.5 \mathrm{mg} / \mathrm{kg} \mathrm{BW} /$ day $)$ and fluorouracil $(15 \mathrm{mg} / \mathrm{kg} \mathrm{BW} /$ day $)$. Data are given as mean \pm S.D., $n=5$. a-d: The same superscript in each group at the same period indicates a significant difference $(p<0.05)$. ${ }^{*}$ Significant difference to the control $(p<0.05)$.

に伴う変化は少なかった.

化学療法剂投与直前の対照区及び LF 投与区の腸 中部腸壁筋層の厚み $(\mu \mathrm{m})$ は，それぞれ，40.4土 9.9 及び $57.8 \pm 11.2$ であり，LF 投与区は対照区に 対し有意に厚かった.

LF の経口投与が化学療法剤投与魚の腸中部腸壁 筋層の厚みに及ぼす影響を Fig. 4 に示す。2 週間目 において，C-M 群は C-S 群に対し， C-M 群は C-F 群に対し，それぞれ，有意に低い值（約 30\%の低 下）を示した． 4 週間目については，対照区内の比 較では，各群間に有意な差は認められなかった。ま た，LF 投与区内においても，2 週間目及び 4 週間 目ともに，各群間に差は認められなかった。

対照区と LF 投与区の比較では， 2 週間目，4 週 間目ともに，LF-S 群，LF-M 群，LF-F 群，LF-MF 群はそれぞれ，C-S 群，C-M 群，C-F 群，C-MF 群 に対し，それぞれ，有意に高い值を示した。

化学療法剂投与直前の対照区及び LF 投与区の腸 後部腸壁筋層の厚み（ $\mu \mathrm{m} ）$ はそれぞれ $38.4 \pm 8.7$ 及び $41.3 \pm 11.9$ であった. LF 投与区は対照区に対 し有意に厚かった．腸後部腸壁筋層の厚みについて は，調査した時期を問わず，すべての群間に有意な 差は認められなかった。

また，化学療法剤投与を行った対照区では，糸球 体の萎縮像及び尿細管腔中にエオジン好性の物質が

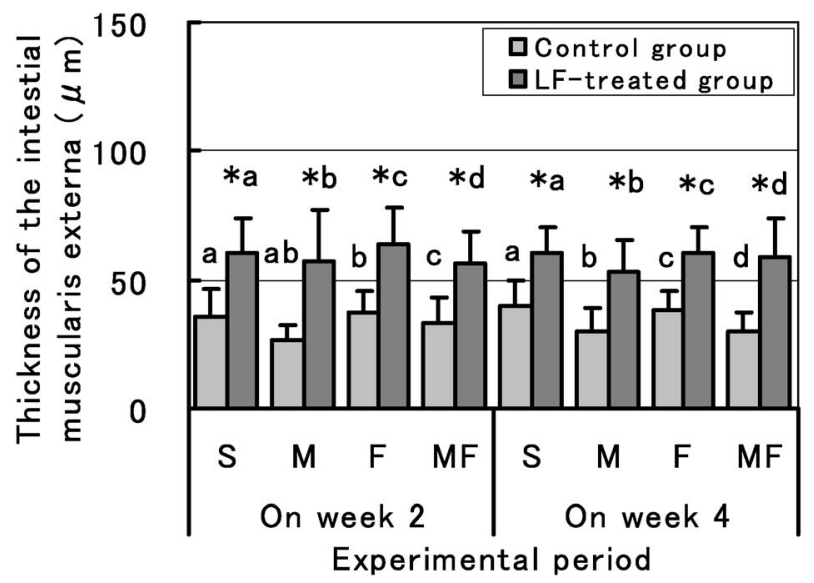

Fig. 4. Changes in Thickness of the Intestinal Muscularis Externa from Goldfish Treated with Chemotherapeutic Agents In LF-treated group, goldfish were fed LF for 3 weeks before the agent treatment. S: saline, M: methotrexate $(2.5 \mathrm{mg} / \mathrm{kg} \mathrm{BW} /$ day $), \mathrm{F}$ : fluorouracil $(50 \mathrm{mg} / \mathrm{kg} \mathrm{BW} /$ day $)$, MF: methotrexate $(2.5 \mathrm{mg} / \mathrm{kg} \mathrm{BW} /$ day $)$ and fluorouracil $(15 \mathrm{mg} / \mathrm{kg} \mathrm{BW} /$ day $)$. Data are given as mean \pm S.D., $n=5$. a-d: The same superscript in each group at the same period indicates a significant difference $(p<0.05)$. *Significant difference to the control $(p<0.05)$.

高頻度で観察された。特に, C-M 群及び C-MF 群 でその傾向は強かった。一方，LF 投与区では，同 一処理をした対照区に比べ，腎組織の変化は著しく 経度であった，肝臟においては，全群間に顕著な差 は認められなかった。

1-7. 腸内細菌数 薬剂投与直前の対照区及び LF 区の腸内全細菌数（105 CFU/g 内容物）はそれ ぞれ $0.68 \pm 0.36$ 及び $0.43 \pm 0.26$ であった。 LF 区と 対照区の間に有意な差はなかった.

LF の経口投与が化学療法剤投与魚の腸内全細菌 数に及ぼす影響を Fig. 5 に示す。LF 区の腸内細菌 数は化学療法剂の投与によってほとんど変化しなか ったものの，対照区の腸内全細菌数は， 2 週間目に いつたんすべての群で有意に増加した．対照区内の 比較では, 2 週間目において C-M 群, C-F 群, CMF 群は C-S 群に対して有意に高い值を示したが, 各化学療法剂投与群の間に有意な差は認められなか つた．LF 投与区内においては，各群間に差はなか つた４ 週間目については，対照区の值は薬剤投与 前のレベルに低下するとともに，対照区内の比較で は，各群間に有意な差は認められなかった。 LF 投 与区内の比較でも, 各群間に差はなかった。

対照区と LF 投与区の比較では，2 週間目におい て，LF-S 群，LF-M 群， LF-F 群，LF-MF 群は， C-S 群， C-M 群， C-F 群， C-MF 群に対し，それぞ 


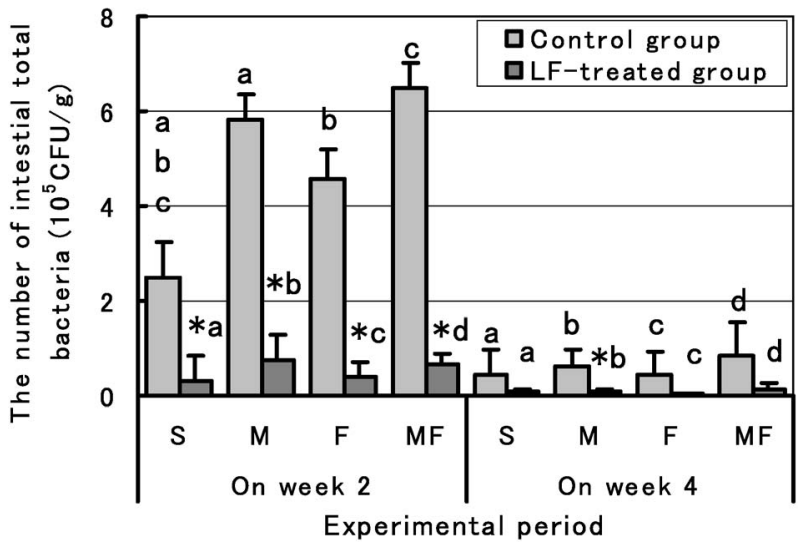

Fig. 5. Changes in the Number of Total Intestinal Bacteria from Goldfish Treated with Chemotherapeutic Agents

In LF-treated group, goldfish were fed LF for 3 weeks before the agent treatment. S: saline, M: methotrexate $(2.5 \mathrm{mg} / \mathrm{kg} \mathrm{BW} /$ day $)$, F: fluorouracil $(50 \mathrm{mg} / \mathrm{kg} \mathrm{BW} /$ day $)$, MF: methotrexate $(2.5 \mathrm{mg} / \mathrm{kg} \mathrm{BW} /$ day $)$ and fluorouracil $(15 \mathrm{mg} / \mathrm{kg} \mathrm{BW} /$ day $)$. Data are given as mean \pm S.D., $n=4$. a-d The same superscript in each group at the same period indicates a significant difference $(p<0.05)$. *Significant difference to the control $(p<0.05)$.

れ，有意に低い值を示した。 4 週間目については,

LF-M 群にのみ，C-M 群に対し有意に低い值がみ られた。

化学療法剂投与直前の対照区及び LF 区の大腸菌 群数 $\left(10^{5} \mathrm{CFU} / \mathrm{g}\right.$ 内容物 $)$ はそれぞれ $0.28 \pm 0.14$ 及び $0.20 \pm 0.15$ であった。 LF 区と対照区の間に有 意な差はなかった。

LF の経口投与が化学療法剤投与魚の腸内大腸菌 群数に及ぼす影響を Fig. 6 に示す。対照区の腸内 大腸菌群数は，2 週間目にいったんすべての群で有 意に増加した，対照区内の比較では，2 週間目にお いて，C-M 群， C-F 群， C-MF 群は C-S 群に対し 有意に高い值を示したが，化学療法剂を投与した群 の間に有意な差は認められなかった。 LF 投与区内 においては，各群間に差はなかった。 4 週間目にお いては，対照区，LF 投与区ともに，同一区内の各 群間に差は認められなかった。

対照区と LF 投与区の比較では，2 週間目，4 週 間目ともに，LF-S 群，LF-M 群，LF-F 群，LF-MF 群は，C-S 群，C-M 群，C-F 群，C-MF 群に対し， それぞれ，有意に低い值を示した。

2. 化学療法剂投与試験 B（LF の同時腹腔内投 与試験） 対照群及び LF 群とも実験期間中, 餌 の食いは良好であった。両群の間において，体重， 体長に有意な差は認められなかった。

2-1. 生残率 LF の腹腔内投与が化学療法剂

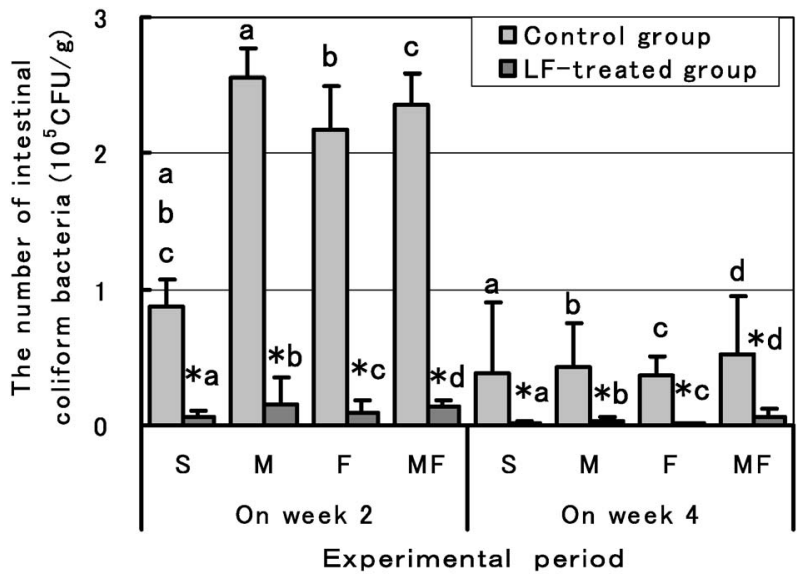

Fig. 6. Changes in the Number of Intestinal Coliform Bacteria (Enterobacteriaceae) from Goldfish Treated with Chemotherapeutic Agents

In LF-treated group, goldfish were fed LF for 3 weeks before the agent treatment. S: saline, M: methotrexate $(2.5 \mathrm{mg} / \mathrm{kg} \mathrm{BW} /$ day $), \mathrm{F}$ : fluorouracil $(50 \mathrm{mg} / \mathrm{kg} \mathrm{BW} /$ day $)$, MF: methotrexate $(2.5 \mathrm{mg} / \mathrm{kg} \mathrm{BW} /$ day $)$ and fluorouracil $(15 \mathrm{mg} / \mathrm{kg} \mathrm{BW} /$ day $)$. Data are given as mean \pm S.D., $n=4$. a-d The same superscript in each group at the same period indicates a significant difference $(p<0.05)$. *Significant difference to the control $(p<0.05)$.

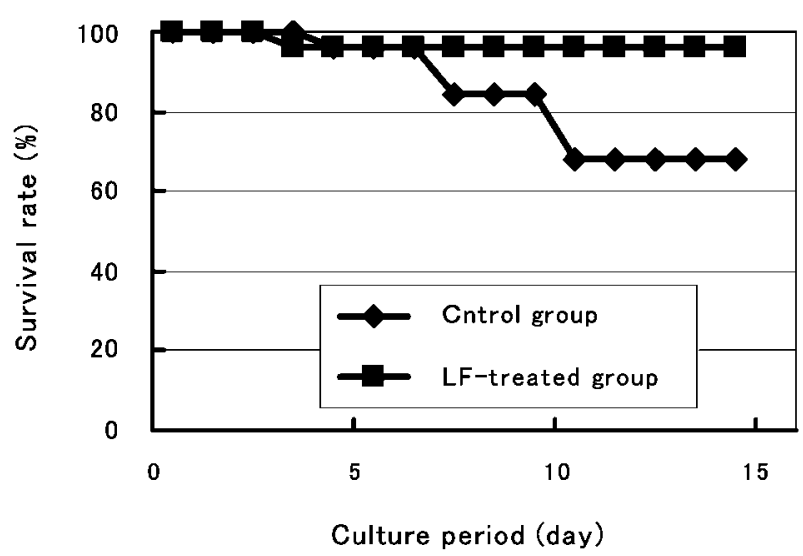

Fig. 7. Changes in the Survival Rate of Goldfish Treated with Methotrexate (MTX)

In LF-treated group, goldfish were injected intraperitoneally LF just after the agent treatment.

投与魚の生残率に及ぼす影響を Fig. 7 に示す。 LF 群では，2 週間目までに 1 尾の死亡がみられたのみ であった（生残率 96\%)。一方，対照群では，1 週 間目当たりから死亡個体が多く認められるようにな り， 2 週間目における生残率は $68 \%$ となった。

2-2. 血球の計測 LF の腹腔内投与が化学療 法剂投与魚の血球数に及ぼす影響を Table 1 に示 す。赤血球数, リンパ球数において，対照群と $\mathrm{LF}$ 群との間に有意な差は認められなかったが，顆粒球 数は LF 群で有意に高い值を示した。 
2-3. 顆粒球の貪食率及び NBT 還元活性 LF の腹腔内投与が化学療法剤投与魚の顆粒球の食食率, NBT 還元活性に及ぼす影響を Fig. 8 に示す。顆粒 球の食食率及び NBT 還元活性は，LF 群において 有意に高かった。

2-4. 血漿中の一価イオン濃度 対照群及び $\mathrm{LF}$ 群の血漿中の $\mathrm{Na}, \mathrm{K}, \mathrm{Cl}$ の濃度 $(\mathrm{mEq} / \mathrm{l})$ はそ れぞれ $125.8 \pm 10.3$ 及び $131.0 \pm 6.8,4.4 \pm 1.7$ 及び $3.3 \pm 1.2,103.2 \pm 6.3$ 及び $102.0 \pm 2.3$ であった。対 照群と LF 群の間で， $\mathrm{Na}, \mathrm{K}, \mathrm{Cl}$ の值に有意な差は 認められなかった。

\section{2-5. 組織学的観察 腸管の上皮細胞について} は, 対照群には化学療法剤投与試験 $\mathrm{A}$ と同様の変 化が認められた。一方，LF 群では，上記の化学療 法剂投与に伴う変化は少なかった。

LF の腹腔内投与が化学療法剂投与魚の腸中部腸 壁筋層の厚みに及ぼす影響を Fig. 9 に示す。LF 群 における腸中部腸壁筋層の厚みは，対照群に比べ， 有意に厚かった。また，化学療法剤投与後 2 週間目 における対照群及び LF 群の腸後部腸壁筋層の厚み $(\mu \mathrm{m})$ は， $41.5 \pm 6.9$ 及び $44.6 \pm 5.8$ となり，両者 の間に有意な差は認められなかった。

体腎組織では，対照群は LF 群に比べ，糸球体の 萎縮及び尿細管腔中にエオジン好性の物質が高頻度 で観察された。肝臟には，対照群と LF 群の間に顕 著な差は認められなかった。

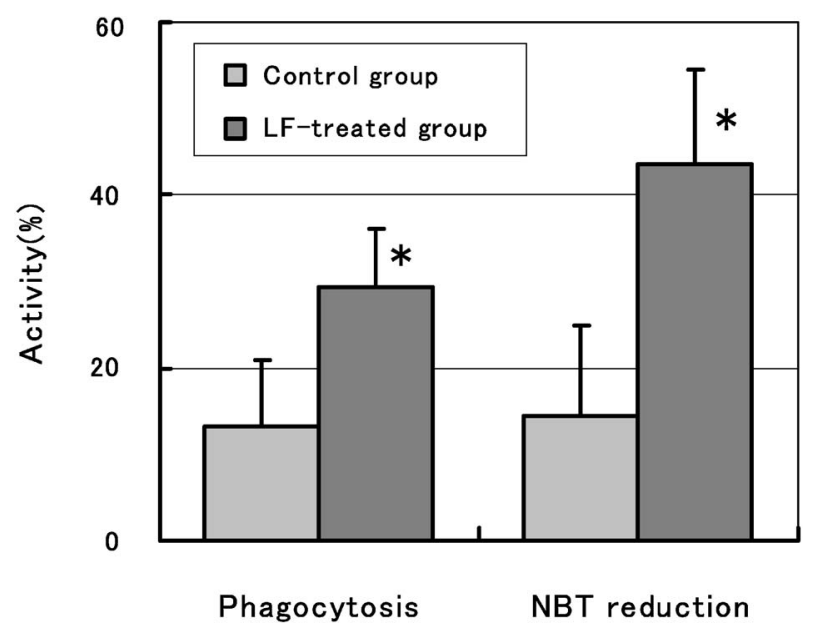

Fig. 8. Changes in the Phagocytic and NBT Reduction Activity of Granulocytes from Goldfish Treated with MTX

In LF-treated group, goldfish were injected intraperitoneally LF just after the agent treatment. Data are given as mean \pm S.D., $n=5$. *Significant difference of the control $(p<0.05)$.
2-6. 腸内細菌数 $\quad \mathrm{LF}$ の腹腔内投与が化学療 法剂投与魚の腸内細菌数に及ぼす影響を Fig. 10 に 示す．化学療法剂投与後 2 週間目における LF 群の 腸内全細菌数及び大腸菌群数は，対照群に対し，有 意に低い值を示した。

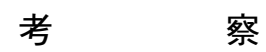

MTX 及び FU は，ほ乳類の各種腫瘍や絨毛性疾 患の治療等に広く使用されている化学療法剤であ

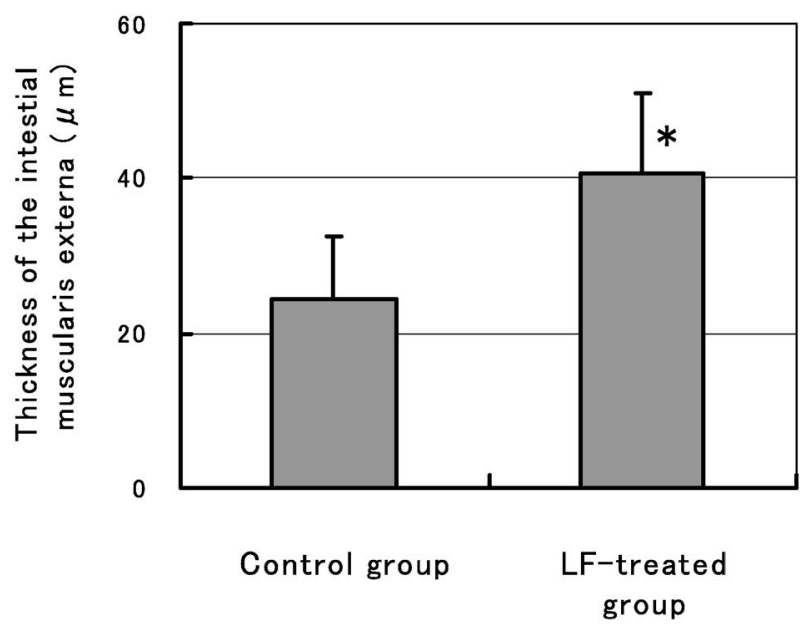

Fig. 9. Changes in the Thickness of the Intestinal Muscularis Externa from Goldfish Treated with MTX

In LF-treated group, goldfish were injected intraperitoneally LF just af ter the agent treatment. Data are given as mean \pm S.D., $n=5$. *Significant difference of the control $(p<0.05)$.

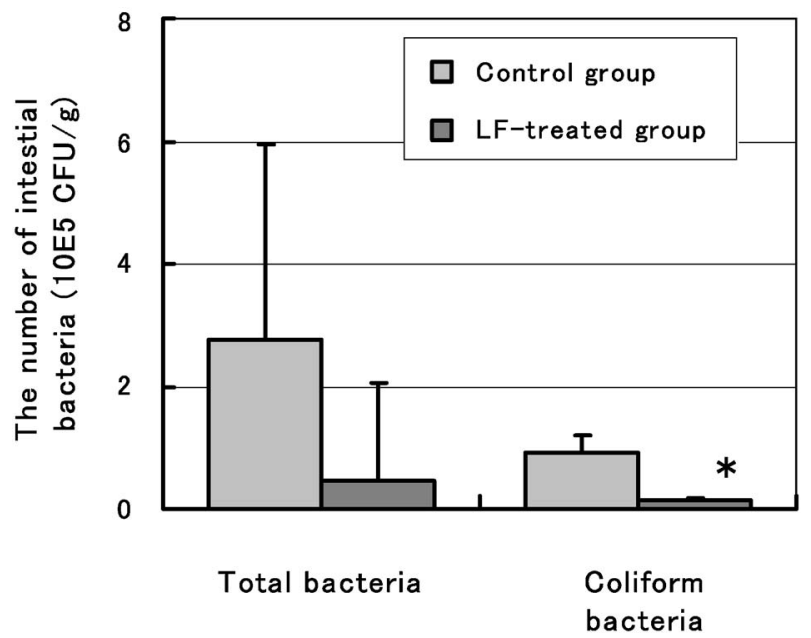

Fig. 10. Changes in the Number of Intestinal Total and Coliform Bacteria (Enterobacteriaceae) from Goldfish Treated with MTX

In LF-treated group, goldfish were injected intraperitoneally LF just after the agent treatment. Data are given as mean \pm S.D., $n=5$. *Significant difference of the control $(p<0.05)$. 
る. 両化学療法剤は分裂細胞に対し選択的に作用す

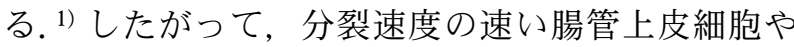
免疫細胞は強い影響（副作用）を受け，その増殖は 抑制される，MTXの投与は，ほ乳類では，1-2 日 目に細胞性免疫活性に，3４日目には小腸の上皮組 織に4)それぞれ，最も強い傷害を与えることが報告 されている．FUも，ほぼ同時期に，消化管及び口 腔粘膜組織の異常等の副作用が表れる。5) そのた め，本実験では，魚の代謝速度を考慮し（ほ乳類の 体温 36-39 ${ }^{\circ} \mathrm{C}$ に対し，今回使用した魚の体内温度は $20^{\circ} \mathrm{C}$ 前後であるため, $\mathrm{Q}_{10}=2-3$ より, 化学療法剤 の影響がでるまでの時間をほ乳類の 4-9 倍と推定し た），取り上げ時期を 2 週間目及び 4 週間目とし た。 また，両化学療法剤の投与量については，ヒト への投与量を参考とした（MTX; 1.25-10 mg/kg/ 日 : FU; $5-20 \mathrm{mg} / \mathrm{kg} /$ 日).

MTX の投与は，FU 投与に比べて，高い死亡率 を示すとともに，大きな生理障害を生じさせた。 す なわち，MTX の投与は，血球の数や組成，血漿中 の一価イオン組成（少なくとも浸透圧）等に影響を 与えなかつたものの，顆粒球の貣食率を低下させる とともに，腸中部の組織に以下のような著しい障害 を生じさせた（ 2 及び 4 週間目）：粘膜ひだの肥厚 や高さの低下，粘膜上皮組織への顆粒球の浸潤，一 部の陰窩は粘膜筋板に近接, 腸壁筋層の厚みの著し い減少，機械的な切れ易さや脆さの増大. これらの 結果は，MTX を投与したキンギョでは，非特異的 な細胞性免疫活性の低下，腸中部における粘膜上皮 の分裂と機能障害及び平滑筋の萎縮や薄層化による 腸の保護・生体防御・運動等諸機能の障害が生じて いた可能性を強く示唆する。.さらに，MTX 投与群 の魚では，腎臓において，腎糸球体の萎縮や尿細管 腔中のエオジン好性物質の存在等が認められてお り，糸球体腎炎に近い症状が現れている可能性があ る.また, 肝臓についても, 光学顕微鏡による観察 によって化学療法剤投与に伴う顕著な変化は認めら れなかったものの，一部個体では，血中のグルタミ ン酸ピルビン酸アミノ基転移酵素（EC 2.6.1.2 LAlanine: 2-oxoglutarate aminotransferase, ALT) の 活性上昇が観察されている（未発表）ことから，当 該個体では軽度の肝障害が生じていた可能性が高 い. なお，MTX 投与群の魚では，鱗が剥がれ易く なっていたことから，体表構造にもなんらかの異常
が生じていた可能性が示唆されたが，今回は体表の 組織学的観察を行っていないため，詳細は不明であ る.

腸内全細菌数については，化学療法剤の投与によ って 2 週間目に，投与直前に比べて高い值がみられ たものの，生理食塩水のみを投与した C-S 群でも 值の上昇が認められたことから，当該反応は化学療 法剂投与の影響に加えて，投与操作に伴って生じた ストレスが影響した結果であると考えられる。ただ し，腸内の大腸菌群数は，MTXの投与により有意 に増加（2 週間目）した。魚類においての善玉菌, 悪玉菌は明らかになってはいないが，ほ乳類では腸 内環境の悪化に伴って大腸菌群数が増加することが 知られている20)ことから，この変化は，MTXの投 与によって腸内環境の悪化が引き起こされていたこ とを暗示する。

一方，FU の単独投与では，腸内の全細菌数や大 腸菌群数は有意に増加（2 週間目）したものの，そ れ以外の調査項目に大きな変化は認められなかっ た．ほ乳類では，FU の投与により，腸管，肝臓等 に重篤な副作用が現れるとされている5,21)が，今回 の実験ではそれほど強い影響はみられなかった。

MTX と FU の混合投与は, MTX の単独投与時 に比べ，生残率をわずかに高めた。ただし，他の調 査項目については，MTX 単独投与時と類似した副 作用を示した。 MTX と FU の混合投与は，FU の 抗腫瘍効果増強のため使用される方法である。化学 療法剤の混合投与により薬理動態が変化し，正常細 胞に対する毒性が軽減されることが知られてい る. 22) しかし，本研究においては，FUによる明確 な副作用軽減効果を確認することはできなかった.

今後, FU 単独投与並びに MTX と FU の混合投与 の影響（副作用の機序や軽減法）については，詳細 な検討が必要である.

MTX 及び FU の投与は，魚においても様々な副 作用を誘起した。ただし，その発現時期について は，当初の予測とは異なり，生体防御活性，腸管組 織ともに 2 週間目からその影響は現れ，後者につい ては影響が長く続く傾向にあった。また，化学療法 剤を投与した対照群のキンギョには死亡個体が認め られた。このことは，当該薬剤の魚への投与時に は，ほ乳類に使用する場合に比べて，用量を減らす 必要性のあることを示す。したがって，実際に化学 
療法剤を魚の腫瘍治療に用いる場合には，魚種によ る感受性差や代謝速度等に関する検討が必要となろ う.

上述したように，化学療法剤の投与は様々な副作 用を誘起した。特に，MTX 投与魚に認められた腸 壁筋層の厚みの低下，腸管の脆さ・切れ易さ，腸内 での大腸菌群数の増加, 腎臓における組織異常, 鱗 の剥がれ易さ（体表構造の異常）等は，ほ乳類での 報告もなく，初めての所見であるが，軽減すべき重 要な事象である.

LF は，乳汁を含め分泌液中に含まれる，鉄結合 性蛋白質であり，それ自体が静菌や抗菌活性を示す ほか，1）体内の非特異的生体防御機構を賦活 化 ${ }^{23,24)}$ するとともに，2）腸管内における Enterobacteriaceae の過剩増殖を抑制する（腸内環境を安 定化させる）ことにより腸内細菌の体内への侵入を 抑えること ${ }^{20,25)}$ や，3）化学療法剤を投与したマウ スの細胞性及び液性免疫反応の抑制16) や小腸上皮細 胞の障害を軽減すること年等が報告されている．本 研究の結果，LF の事前の経口投与は，化学療法剂 を投与したキンギョの顆粒球の数, 食食率や NBT 還元活性を高く保つとともに，腸管内の全細菌数や 大腸菌群数を抑制したり，腸中部の粘膜ひだの肥厚 や高さの低下，顆粒球の粘膜上皮組織への浸潤等か ら予測される腸の各種機能障害を軽減したりするこ とが判った．すなわち，LFは，魚においても，上 記 1)，2）,3)のすべての項目で，同様のポジティブ 効果を示すことが明らかとなった（但し，今回の実 験では液性免疫反応については検討していない)。 加えて, 従来の報告にはなかった化学療法剤による 副作用の軽減効果，すなわち 4）腎臓の障害軽減, 5）腸壁筋層の厚みの低下，腸管の脆さ・切れ易さ (平滑筋組織の障害)，6）鱗の剥がれ易さ等に対し て著しい改善効果を示すことも判った.

LF の生体防御効果の発現機序としては，（1）消 化管から吸収された LF あるいはその分解物による 標的器官や細胞への直接作用，（2）腸管内における 静菌作用に伴う直接作用，（3）腸内細菌の効用に伴 う腸管免疫組織の活性化を介した間接作用，という 3 通りが考えられる。ただし，(2) と（3）は，腸内環 境の安定化に負うところが多いという点では，似か よっている.

LF はそれ自身，強い抗菌活性を有するものの，
経口投与の場合，分子量約 8 万の LF 分子がそのま まの状態で体内に容易に吸収され，各種作用を引き 起こすとは考え難い。ただし，ウサギの抗牛 LF 血 清から精製した $\operatorname{IgG}$ 分画を用いた ELISA のサンド イッチ法による測定では，牛 LF を投与したマダイ の体表粘液から，未投与魚に比べて高い濃度の LF が検出されたこと年)から，経口投与した LF あるい は（上記抗体との反応部位を保持した）LF 分解物 が体内に吸収された可能性を否定することはできな い. 加えて，顆粒球は LF を放出し，マクロファー ジの機能調節に関与しているとの報告がある. ${ }^{23)} し$ たがって，(1)については，魚においても，体内に 吸収された牛の LF あるいは LF 分解物, 及び牛 LF の投与により血中に増加した顆粒球が放出した LF が，標的器官や細胞に直接作用を及ぼした可能 性はある。

LF の投与がマウスの消化管内において，Enterobacteriaceae の増殖を抑制したり，経口的に投 与した Clostridium sp.の腸内増殖を抑制したりす

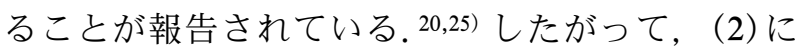
ついては，魚においても，LFによる腸内細菌の静 菌作用の結果として, 腸内細菌の腸管から藏器への 侵入が著しく抑えられていた可能性が高い.ただし， LF を投与した魚では，化学療法剤の投与下でも， 腸上皮組織の異常は少なく，腸中部における腸壁筋 層の厚み減少もなく健常時に近い状態に保たれてい たことなどから，腸内細菌の侵入阻止には，LFの 腸壁保護効果，すなわち腸の物理的及び生物的障壁 保守・増強作用も重要な役割を担っていたことが判 る.

ほ乳類では，LF の投与が数種のサイトカイン産

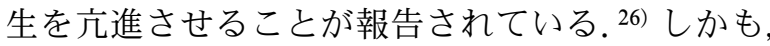
このサイトカイン産生の亢進には小腸の上皮細胞が 深く係わっており，そこで産生されるインターロイ キン（IL）-15 や IL-18 というサイトカインはある 種の $\mathrm{T}$ 細胞やナチュラルキラー（NK）細胞の活性 を高め, インターフェロン $\gamma$ の産生を更新させるこ とが知られている. ${ }^{26)}$ 魚類のサイトカイン産生やそ の役割，調節機構に関する研究は極めて少な $<, 27-29)$ 小腸の上皮細胞由来のサイトカインに関す る情報も見当たらない。しかし，魚においても， $\mathrm{LF}$ の投与が NK 細胞の活性を高めることが報告さ

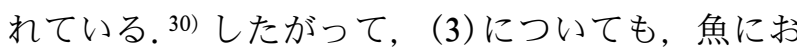


いて，LF が腸管内の環境を安定化させるととも に, サイトカイン産生細胞を刺激し，生体防御活性 を上昇させることで，化学療法剤投与に伴う生体防 御活性の低下軽減あるいは補完に機能していたと考 えることができる.

LF の腸管粘膜組織の障害軽減効果については, ラットにおいて，細胞増殖を刺激する作用を有する グルカゴン様ペプチド -2（GLP-2）の分泌抑制を 介して細胞の分裂速度を低下させることで，分裂速 度の速い腸管上皮細胞等に対する化学療法剂の選択

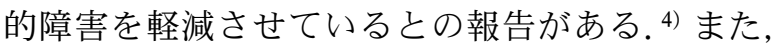
LF は腎組織に炎症性障害を生じさせるプロスタグ ランジン（PG）E2の分泌抑制作用 ${ }^{31)}$ や活性酸素除 去活性 ${ }^{32)}$ を有することが報告されている。 したがつ て，魚においても，LFが同様の作用機序により腸 管粘膜組織や腎組織の障害軽減に働いているものと 考えられる。

しかしながら，今回の実験でみつかつた LFによ る腸壁筋層の障害軽減や鱗の剥がれ易さの改善等に ついては, 今回調査した化学療法剂投与に伴う発生 機序とともに，その作用機序は不明である．MTX のような化学療法剤の投与が腸管平滑筋の萎縮や薄 層化を引き起こすとすれば，その影響は腸管中部に 留まらず，(今回の調査では腸管後部に著しい障害 は認められなかつたが）消化管各部や血管壁等の全 身に及ぶ可能性があることから，LF の影響軽減効 果の機序については至急の調査が必要である。

ところで，今回の試験では，LF の同時腹腔内投 与によっても同様の効果の得られることが判った. LF の事前投与のみでなく, 同時投与によって化学 療法剂の副作用を軽減できることは，LF のより実 践的な使用につながり，今後，高級観賞魚や絶滅危 惧種への化学療法剤による腫瘍治療等への応用も期 待できる.

ただし，LF の腹腔内投与による化学療法剤の副 作用軽減効果については，経口投与時とは作用伝播 の方向や効果発現に至るまでの期間が大きく異なつ た。すなわち，牛 LF は大型の異種蛋白質でありな がら，体内に直接投与されても魚に過度の炎症反応 を引き起こさなかったばかりか，経口時とは逆の方 向（腹腔内から腸管壁や腸管内部等）への作用伝播 を含め，効率よく上記軽減効果を表した。腹腔内に 投与された LF あるいはその分解物が直接的に， あ
るいは免疫担当細胞内，腸管壁や腸管内部等に取り 込まれることによって間接的に，同様の作用を惹起 した可能性はある。 しかし，このような LF の効果 及びその発現機序については，これまで報告例がな く, 今後, 解明に至る詳細な研究実施が急がれる.

今回使用した化学療法剤である MTX と FU は, ともに代謝拮抗剤（前者は葉酸拮抗剤, 後者はピリ ミジン拮抗剤）であり，細胞中に取り込まれて核酸 の代謝を阻害することにより癌細胞の分裂を防ぐも のである. ${ }^{33)} \mathrm{LF}$ については，これらの作用を阻害 するあるいは作用と拮抗するような構造や働きはこ れまで報告されていない ${ }^{34-38)}$ ことから，LF の投与 が当該化学療法剂の抗腫瘍性を消失あるいは軽減さ せることはないと考えられる，ただし，今後，腫瘍 を持つ生物を対象として，当該化学療法剂や作用機 序の異なつた化学療法剤と LF の複合投与試験を実 施し，上記問題について，その真偽を明らかにして いく必要があると考える.

最後に, 今回の実験では, 化学療法剂投与後 2 週 間目及び 4 週間目の生理機能変化を指標として，そ の副作用を調べるとともに，LF 投与による副作用 軽減効果を調査した。しかしながら，化学療法剤の 副作用にはより短期間に起こるものもあると考えら れることから，今後，化学療法剂処理後 1 週間以内 に生じる副作用や LF によるその軽減効果について の調査も必要であろう.

\section{REFERENCES}

1) Nitta K., Yuuki Gousei Kagaku Kyokai Shi, 49, 968-979 (1991).

2) Yamauchi A., Ichimiya T., Inoue K., Taguchi Y., Matsunaga N., Higuchi S., Ohdo S., Koyanagi S., Fukagawa T., Aramaki H., J. Pharmacol. Sci., 99, 335-341 (2005).

3) Artym J., Zimecki M., Kruzel M. L., Anticancer Res., 24, 3831-3836 (2004).

4) van't Land B., van Beek N. M. A., van Den Berg J. J. M., M'rabet L., Dig. Dis. Sci., 49, 425-433 (2004).

5) Yamamitsu S., Hirada K., Shirasaka T., Hematol. Oncol., 49, 485-490 (2004).

6) Arnold R. R., Brewer M., Gauthier J. J., Infect. Immun., 28, 983-898 (1980) .

7) van der Strate B. W., Beljaars L., Molema G., Harmsen M. C., Merjer D. K., Antiviral Res., 
52, 225-239 (2001).

8) Wakabayashi H., Yamauchi K., Taraguchi S., Hayasawa H., Uchida K., Yamaguchi H., J. Antimicrob. Chemother., 46, 595-601 (2000).

9) Tanaka T., Omata Y., Saito A., Igarashi I., Suzuki N., Shimazaki K., J. Vet. Med. Sci., 58, 61-65 (1996).

10) Kakuta I., Kurokura H., Fish Pathol., 30, 289290 (1995).

11) Lu L., Hangoe G., Oliff A., Chen L. T., Shen R.-N., Broxmeyer H. E., Cancer Res, 47, 41844188 (1987).

12) Bezault J., Bhimani R., Wiprovnick J., Furmanski P., Cancer Res., 54, 2310-2312 (1994).

13) Yoo Y., Watanabe S., Watanabe R., Hata K., Shimazaki K., Azuma I., Jpn. J. Cancer Res., 40, 257-262 (1997).

14) Sekine K., Watanabe E., Nakamura J., Takasuka N., Kim D. J., Asamoto M., Krutovskikh V., Baba-Toriyama H., Ota T., Moore M. A., Masuda M., Sugimoto H., Nishino H., Kakizoe T., Tsuda H., Jpn. Cancer Res., 88, 523-526 (1997).

15) Artym J., Zimecki M., Kruzel M. L., Med. Sic. Monit., 10, BR 84-89 (2004).

16) Bartal L., Padeh S., Passwell J. H., Pediatr. Res., 21, 54-57 (1987).

17) Ito M., Fujimaki Y., Hatai Y., Isoda M., Jpn. Vet. Stockbreeding Univ. Res. Rep., 33, 151155 (1984).

18) Okihiro M. S., Groff J. M., Hinton D. E., Whipple J. A., Cancer Res., 53, 1761-1769 (1993).

19) Vogelbein W. K., Van Veld P. A., Huggett R. J., Fourin J. W., Cancer Res., 50, 5978-5986 (1990).

20) Ogata T., Terao S., Hayasawa H., Milk Sci., 46, 233-238 (1997).

21) Hirano T., Miyazaki K., Gekkan Yakuji, 40, 867-872 (1993) .

22) Sasaki T., Jpn. J. Cancer Chem., 23, 1907-
1910 (1996).

23) Lima M. F., Kierszenbaum F., J. Immunol., 139, 1647-1651 (1987).

24) Kakuta I., Kurokura T., Nakamura H., Yamauchi K., Suisanzoshoku, 44, 197-202 (1996).

25) Crouch S. P., Slator K. J., Fletcher J., Blood, 80, 235-240 (1992).

26) Okamura H., Kashiwamura S., Tsutsui H., Yoshimoto T., Nakanishi K., Curr. Opin. Immunol., 10, 259-264 (1998).

27) Kono T., Fuiki K., Nakano M., Yano T., Endo M., Sakai M., J. Interferon Cytokine Res., 22, 413-419 (2002).

28) Wang T., Holland J. W., Secombes C. J., Bols N., FEBS J., 272, 1136-1147 (2005) .

29) Wen Yi., Shao J., Xiang L., Fang W., Comp. Biochem. Physiol., 144B, 159-166 (2006).

30) Kakuta I., "'Lactoferrin: Structure, Function and Applications,", eds. by Shimazaki K., Tsuda H., Tomita M., Kuwata T., Perraudin J. P., Elsevier, Amsterdam, 2000, pp. 429441 .

31) Bartal L., Pedeh S., Passwell J. H., Pediatr. Res, 21, 54-57 (1987).

32) Cohen M. S., Mao J., Rasmussen G. T., Serody J. S., Britigan B. E., J. Infect. Dis., 166, 1375-1378 (1992).

33) Chemotherapy drugs, http://www.chemocare. com/ (Fluorouracil; http://www.chemocare. com/bio/fluorouracil.asp, Mrthotrexate; http:// www.chemocare.com/bio/methotrexate.asp)

34) Shimazaki K., Kiyasawa I., Biosci. Ind., 151, 25-27 (1993).

35) Levary P. F., Viljoen M., Haematologica, 80, 252-267 (1995).

36) Kakuta I., Bioindustry, 15, 23-33 (1998).

37) Harada E., Mansei toutsu, 23, 9-23 (2004).

38) Wakabayashi H., Takakura N., Yamauchi K., Tamura Y., Clin. Vaccine Immunol., 13, 239245 (2006). 